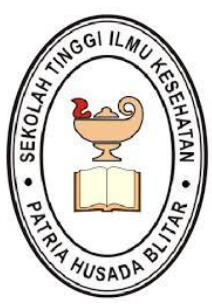

JNK

JURNAL NERS DAN KEBIDANAN (JOURNALOFNERS AND MIDWIFERY) http://jnk.phb.ac.id/index.php/jnk

\title{
The Effectiveness of In-Network Methods (Whatsapp Group) to the Attitudes of Covid 19 Prevention of D3 Midwifery Students STIKes Patria Husada Blitar
}

Ita Noviasari ${ }^{1}$, Levi Tina Sari ${ }^{2}$

${ }^{1,2}$ Departement of Midwifery, STIKes Patria Husada Blitar, Indonesia

\section{Article Information}

History Article:

Received, 23/09/2020

Accepted, 24/11/2020

Published, 05/12/2020

Keywords:

ovid-19, whatsapp, attitude

\section{Abstract}

Covid-19 is a new type of virus that easily spreads to humans and causes serious infections such as pneumonia. In Indonesia, the PSBB (Large-Scale Social Restriction) was implemented as an effort to suppress the spread of the corona virus. All activities outside the home are stopped or reduced until the pandemic has subsided. Some regions have implemented government policies to dismiss their students and begin the application of learning methods using an online or online system. Methods: The design of this study used a quasy experiment with a pre-post group design approach without control group design. A sample of 19 respondents was given material about the definition of covid-19, prevention of covid-19. The sampling technique used purposive sampling. The data collection method used a questionnaire in the form of google form given to respondents before treatment and after treatment. Data analysis was divided into 2, namely univariate and bivariate. Univariate in the form of frequency distribution to measure the characteristics of respondents, namely age, parent's occupation, and bivariate using the Wilcoxon Signed Rank Test statistical test aimed at distinguishing attitudes before and after treatment. Results: The Wilcoxon test proved that there was a difference between before and after treatment, namely $\alpha(0.05)>$ 0.001. Discussion: Communication with social media via the internet (whatsapps) affected the attitudes of respondents in preventing covid-19 transmission and increase information and understanding for respondents.

(C) 2020 Journal of Ners and Midwifery

\footnotetext{
Correspondence Address:

STIKes Patria Husada Blitar - East Java, Indonesia

P-ISSN : 2355-052X

Email:noviasariita@gmail.com

E-ISSN : 2548-3811

DOI: $10.26699 /$ jnk.v7i3.ART.p410-414

This is an Open Access article under the CC BY-SA license (http://creativecommons.org/licenses/by-sa/4.0/)
} 


\section{INTRODUCTION}

Lately, corona is still a hot topic of conversation and still dominates in society. Covid is currently a trending topic that is widely reported in both print and electronic media. SARS-COV-2 (Severe Acute Respiratory Syndrome Coronavirus 2) or the corona virus is a new type of corona virus that causes infectious diseases to humans. Corona Virus Disease 2019 or called Covid-19 is a virus that was first discovered in Wuhan China in December 2019.(BNPB, 2019). Then this virus spread and very quickly to almost all countries within a period of a few months, including Indonesia. So that WHO designated this outbreak as a global pandemic. (WHO, 2020).

In June 2020, in Indonesia, have 45,891 confirmed positive, 2,465 deaths, 56,436 people under surveillance and 13,225 patients under surveillance (Satgas Penanganan covid-19, 2020). In the city of Blitar there are 4 positive cases, 3 recovered and 1 still under treatment, 209 people under surveilans, with details of 203 people being monitored, 4 people being monitored and 2 people dying (Media Indonesia, 2020)

This virus can attack anyone from infants, children, adults and the elderly, including pregnant and lactating women. Corona virus is a collection of viruses that can infect the respiratory system. In some cases it causes only mild respiratory infections such as influenza only. But this virus can cause respiratory infections that are quite severe such as lung infections (pneumonia) (Sari, 2020)

In preventing the corona virus, several countries have established policies, namely imposing lockdowns. Indonesia imposed Large-Scale Social Restrictions as an effort to suppress the spread of the virus corona. All activities outside the home are stopped or reduced until the pandemic has subsided. Some areas of government policy applied to dismiss the students and start implementing a learning method in a network or online system This is in accordance with Decree No.4 of 2020 concerning Implementation of Education Policies in an Emergency Period of the Spread of the Coronavirus by the Minister of Education and Culture. Where the learning system is carried out through a personal computer or laptop device connected to the internet network. Learning can also be done through groups on social media such as WhatsApp, telegram, zoom or other media as a learning tool. So that in this condition, the teacher can still monitor and ensure that students take part in learning even though they are in different places. (Kemendikbud, 2020)

Lots of appeals have been made by the government in an effort to break the chain of transmission of Covid 19. By maintaining physical distance, working from home, studying from home and worshiping at home. It is expected to maintain physical distance to minimize the risk of splashes or droplets or touching objects that were previously exposed to droplets. Some guidelines for prevention include frequent hand washing, avoiding touching the face area, avoiding sharing personal items, avoiding shaking hands and hugging, maintaining social distancing and avoiding large gatherings. The government has provided rules not to carry out crowd activities during the pandemic and to carry out activities at home so that it is expected to reduce the spread of covid 19 (Kemendikbud, 2020).

University as an institution that has a moral responsibility to educate the nation's life is expected to provide a different atmosphere in the world of education that can support a creative and innovative learning process. But to achieve this, there are currently obstacles due to the pandemic which limits the space to interact directly and implement health protocols. Therefore, one way is by using the online method (whatsapp).

According to Statistical data through the Statista website, 2019 shows an increase in the number of active WhatsApp users every month around the world. At Indonesia in February 2017 there were 1,000 billion active WhatsApp users and in January 2019 it increased to 1,200 billion WhatsApp active users (Kominfo, 2019). WhatsApp is a cross-platform instant messaging service for smartphones that rely on the internet to send messages. Based on its specifications whatsapp is low cost, making it a cheap alternative to sending text messages, especially for international and group messages (Wong et al, 2018). So the material about Covid 19 through the WhatsApp group is expected to be an alternative for conducting health education or counseling because it will be right on target and the message conveyed can be understood (Delam et al, 2019).

Researchers are interested in conducting research on the effectiveness of online methods (group whatsapp) on attitudes to preventing Covid 19 in D3 Midwifery students STIKes Patria Husada Blitar. 


\section{METHODS}

The design of this study used a quasy experiment with a pre-post group design approach without control group design. The population in this study were all students of D3 Midwifery STIKes Patria Husada Blitar. Sampling technique used purposive sampling with inclusion criteria as actived student, participated in the study from began to end, so that a sample obtained by 19 students. 19 respondents were given material about the definition of covid-19, and prevention of covid-19. Methods of data collection used a questionnaire in the google form given to respondents before treatment and after treatment. treatment was carried out for 4 weeks and time can be carried out at any time. The variable measured the attitude of prevention of covid 19, the attitude questionnaire was divided into favorable and unfavorable statements. Measurement of attitudes used a Likert scale, namely 1: strongly disagree, 2 : disagree, 3 : neutral, 4: agree, 5: strongly agree. The data scale was ordinal with a positive attitude category: score $\mathrm{T} \geq$ mean coded 2, negative attitude: score $\mathrm{T} \leq$ mean coded 1.

Data analysis was divided into 2, namely univariate and bivariate. Univariate form to measure the frequency distribution characteristics of the respondents, aged, occupation of parents, and bivariate used statistical test of Wilcoxon Signed Rank Test aims to differentiate attitudes before and after treatment.

\section{RESULTS}

\section{General Data}

Table 1 Characteristics of Respondents $(n=19)$

\begin{tabular}{lcc}
\hline Characteristics & $\Sigma$ & $\mathbf{\%}$ \\
\hline Age & & \\
-20 & 6 & 32 \\
-21 & 5 & 26 \\
-22 & 8 & 42 \\
\hline Parents' job & 2 & \\
- government officials & 11 \\
- Private sector employee & 4 & 21 \\
- merchant & 10 & 53 \\
- farmer & 3 & 15 \\
\hline Have received covid information: & & \\
- yes & 19 & 100 \\
- no & 0 & 0 \\
\hline
\end{tabular}

If (ever) the source of the information:

- Mass media 115

$\begin{array}{lll}\text { - Internet } & 17 & 90\end{array}$

- Health workers $\quad 000$

- Covid task force 115

- Friend 000

\section{Custom Data}

Table 2 Attitude Before Treatment

\begin{tabular}{lcc}
\hline Characteristics & $\Sigma$ & $\mathbf{\%}$ \\
\hline Positif & 8 & 42 \\
Negatif & 11 & 58 \\
\hline Total & $\mathbf{1 9}$ & $\mathbf{1 0 0}$ \\
\hline
\end{tabular}

From the table above proves that the respondents have a negative attitude by $58 \%$.

Table 3 Attitude After Treatment

\begin{tabular}{lcc}
\hline Characteristics & $\sum$ & $\boldsymbol{\%}$ \\
\hline Positif & 19 & 100 \\
Negatif & 0 & 0 \\
\hline Total & $\mathbf{1 9}$ & $\mathbf{1 0 0}$ \\
\hline
\end{tabular}

The results of research above prove that the positive attitude of respondents to the prevention of Covid19 was 19 respondents.

Table 4 The numerical value of the Wilcoxon sign rank test

\begin{tabular}{lcccc}
\hline & $\mathbf{N}$ & Mean & $\mathbf{Z}$ & Asymp.sig (2-tailed) \\
\hline $\begin{array}{lccc}\text { Before } \\
\text { After }\end{array}$ & 19 & 1,42 & \multirow{2}{*}{3,317} & 0.001 \\
\hline
\end{tabular}

From the table above proves that there is a difference between before and after treatment, namely $\alpha(0.05)>0.001$. there is an increase in the mean value between before and after treatment by 0.58 points.

\section{DISCUSSION}

The results showed that $58 \%$ of respondents had negative attitudes towards the prevention of 
Covid-19 before treatment. This waas due to the lack of information obtained, because covid-19 spreads very quickly and the government quickly orders to be at home, so respondents did not get direct counselled from health workers but from the internet. Then covid-19 was a new thing or virus so that it is less known by the public or the public.

In Indonesia, there was a big spike in cases of Covid-19. Initially there 134 people affected with the number of deaths of five people, then the information affected increased to 227 with the death of 19 people (Media Indonesia, 2020). Therefore, the government gave instructions for closed lectures due to the massive spread of Covid-19. So that students, especially respondents, did not get valid information about Covid-19.

The government conducted covid-19 counselled through mass and electronic media and was also encouraged and formed a covid 19 task force, but this not been able to shape the attitude of the community, especially respondents in terms of prevented Covid-19, and accorded to respondents, prevention only done used masks. In addition, there were some people who provided wrong information, which resulted in the transmission of covid-19.

The environment around the respondent's house and the work of parents can also influence the formation of attitudes towards the prevention of Covid 19. The environment can shape a person's character because it's done continuously (Purwanto, 2009). So because of the lack of Covid information, the environment around the house and family did not or did not complied with the rules in order to prevent Covid 19.

After treatment, the results showed that $100 \%$ of respondents had a positive attitude towards the prevention of Covid-19. The treatment was done during four weeks with time not restricted for the purpose of obtained the trust / confidence of the respondent and before various respondents knew each other and trust each other.

Effendy (2012) revealed that the purpose of provided health education was to achieve changes in attitudes and behavior for both individuals, families and communities so that they can foster and maintain healthy behavior and a healthy environment, and had an active role in realize optimal health status. More and more information can influence or increase knowledge and with knowledge it creates awareness that eventually someone will behave and behave in accordance with the knowledge they had (Notoadmodjo, 2012).

Wawan dan Dewi (2010), attitudes were general evaluations made by individuals of themselves, other people, objects or issues. This can happen because in theory, it reveals that attituded a predisposition (determinant) that gave rise to behavior or actions in accorded with the attituded. Attitude to grow, begun with knowledge that perceived as good (positive) or not good (negative), then internalized into respondents.

Respondents aged 20-23 years where adults easily accept new things positived to improve their health, because they were an adults, health was the main thing because with a healthy body condition they can work, learn actively and productively.

The research results prove that $\alpha(0.05)>$ 0.001 . there was an increased in the mean value between before and after treatment. This because the first few factors were that the respondents already know each other and the treatment lasts for 4 weeks and not limited by time in question and provided input and suggestions, so there trusted between the respondent and the researcher (tentor). And there had been a very massive covid-19 transmission as well as information assistance from various media both mass and electronic so that respondents had a positive attituded in prevented Covid 19.

Communication with social media via the internet (whatsapps) will affect the attituded of respondents in prevented the transmission of covid19 and increased information and understood for respondents. This in accordance with the opinion of Effendi (2010) which states that communication used social media (WhatsApp) a concept and a relatively up to date study area. Communication in this media was the used of android or windows along with the facilities and capabilities to be used as a mass or private messenger (Sari, 2020).

The ability of a counselor (tentor) in research was also given priority, because it determines the flow of communication that adolescents can accepted and had trusted. In research from Kosasih et al (2017), that the ability and knowledge of a communicator was essentially the impression formed by the communicator about the ability of the communicator. A counselor must also have expertised and knowledge. In addition, counselled with the online method via Whats app can be done 
anytime and anywhere, so that adult teens can asked questions without a barrier to distance and time.

Whatsapp social media can present various forms of delivery of messages, both in the form of text, images and can send words, powerpoints, voice notes, and videos, so that it will make it easier for someone to understood the content of the material. education in this research was an effort or activity to create community behavior that was conducive to health. The use of social media very effectived and can created more opportunities for interaction, so that the use of social media as an educational medium can be used as a medium for interaction and information share and effectived for used.(Gikas J \& Grant, 2013:18-25)

\section{CONCLUSION}

The research results proved that $\alpha(0.05)>$ 0.001 . there an increased in the mean value between before and after treatment. 100\% of respondents had a positive attituded towards prevented covid-19 Communication with social media via the internet (WhatsApp) affects the attitude of respondents in prevented the transmission of covid19 and adds information and understood to respondents.

\section{SUGGESTION}

The most effectived means of provided information and trained during the COVID-19 pandemic era was used the internet, the wich one was the WhatsApp group. Where this WhatsApp already owned by all teenagers so they can easily accessed it.

\section{REFFERENCES}

BNPB. (2020). Covid 19 di Indonesia, Available at 20 Juni (2020), (www.covid19.go.id)

Delam H, Eidi A (2019) 'WhatsApp Messenger role in Coronavirus Disease 2019 (COVID 19) Pandemic' Journal of Health Sciences \& Survailance System, 8(4), pp.183-184. Doi: $\underline{10.30476 /}$ JHSSS.2020.87202.1107. Available at: $21 \mathrm{Juli}(2020)$ (https://jhsss.sums.ac.ir/article_46964.html)

Effendy, Nasrul. (2012). Dasar \pm Dasar Keperawatan Kesehatan Masyarakat (Ed. 2). Jakarta: EGC.

Effendi, M. 2010. Peranan Internet sebagai Media Komunikasi. Jurnal Dakwah dan Komuniaksi, 4(1).
Gikas, J., \& Grant, M. M. (2013). Mobile computing devices in higher education: Student perspectives on learning with cellphones, smartphones \& social media. Internet and Higher Education. https:// doi.org/10.1016/j.iheduc

Kemendikbud (2020). Penyesuaian Keputusan Bersama Empat Menteri tentang Panduan Pembelajaran di Masa Pandemi COVID-19. Available at: 28 April (2020). (www.kemendikbud.go.id)

Kemendikbud (2020). 19 Juni 2020: Kemendikbud Luncurkan Tiga Kebijakan Dukung Mahasiswa dan Sekolah Terdampak COVID-19. Available at 20 Juni (2020). (https://bersamahadapikorona.kemdikbud. go.id/kemendikbud-luncurkan-tiga-kebijakandukung-mahasiswa-dan-sekolah-terdampak-covid$19 /)$

Kominfo. (2019). Kominfo, WhatsApp Kenalkan Literasi Privasi Dan Keamanan Digital, Available at 20 Juni (2019), (kominfo.go.id).

Kosasih, E. J., Setianti, Y., \& Wahyudin, U. (2017). Pengaruh kredibilitas petugas terhadap sikap kepatuhan pasien tbc pada pemeriksaan dahak. Jurnal Kajian Komunikasi, V ol.5, No.1, pp.1-10

Media Indonesia (2020). Pembelajaran daring. Available at: 21 Juli (2020). (https://mediaindonesia.com/read/ detail/298964-covid-19-dan-pembelajaran-daring)

Notoatmodjo S. (2012). Promosi Kesehatan dan Perilaku Kesehatan. Jakarta: PT Rineka Cipta.

Purwanto. (2009). Evaluasi hasil belajar. Surakarta: Pustaka belajar

Sari, LT (2020). Pengaruh Cyber Counseling Terhadap Sikap Pencegahan HIV/AIDS di SMK PGRI 3 Blitar. Jurnal Penelitian Kesehatan, Jilid 7, No.2, hh: 6370

Sari, IY (2020). Pneumonia COVID-19 Coronavirus disease 2019. Available at: 21 Juli (2020). (www.rssoewandhi.surabaya.go.id)

Satgas Penanganan Covid-19. (2020). Peta Sebaran Covid-19, available at: 20 Juni (2020), (https:// covid19.go.id/peta-sebaran)

Wawan A \& Dewi (2010). Teori dan Pengukuran Pengetahuan, Sikap dan Perilaku Manusia. Yogyakarta: Nuha Medika.

WHO (2020). Coronavirus disease (COVID-19) pandemic. Available at: 25 Juli (2020) (www.who.int)

Wong KP, Bonn G, Tam CL, Wong CP(2018) 'Preferences for Online and/or Face-to-Face Counseling among University Students in Malaysia', Frontiers in Psychology, 9(64), doi: 10.3389/fpsyg.2018.00064. PMID: 29445352; PMCID: PMC5798405 Available at: 25 Juli 2020 (https://www.ncbi.nlm.nih.gov/pmc/ articles/PMC5798405/\#). 